\title{
Assessment of flexible pavement of selected highways in Odo-Otin Local Government South-Western Nigeria
}

\author{
Bello, A. A. ${ }^{1,}{ }^{*}$, Awogboro, O. S. ${ }^{2}$, Ajamagbiso, O. A. ${ }^{3}$ \\ 1, 2, 3 Department of Civil Engineering, Faculty of Engineering, Osun state University, \\ Osogbo, PMB 4494, Nigeria
}

\section{Index Terms}

Flexible Pavement

Pavement Condition Rating

Unconfined Compressive Strength

California Bearing Ratio

Received: 7 May 2016

Accepted: 28 May 2016

Published: 21 June 2016

\begin{abstract}
This paper presents the flexible pavement of selected highways in Odo Otin Local Government Area, Osun State, Southwestern Nigeria. To achieve this, the study involved site observation, Pavement Condition Rating (labeled TP1-TP7), identification of types of failures or distress on the pavement, drainage assessment, and geotechnical studies of the selected Highways. Soil samples were collected from both the unfailed and failed section of the selected roads. The samples were subjected to the following laboratory tests; natural moisture content, sieve analysis, atterberg limit, specific gravity, compaction test using West African standard, unconfined compressive strength, and California bearing ratio. The study revealed that PCR rating scales for TP4, TP6, and TP7 were in good condition because there was less distress on the road. TP3 and TP were in satisfactory condition. TP1 and TP2 were observed to be in poor condition. Only road TP6 and TP7 have effective drainage, but it can be predicted for them to have a blockage or erode other roads in the nearest future due to no discharge outlet. They have no drainage for other roads, leading to major causes of some distress all around those roads. The unconfined compressed strength ranges between $41 \mathrm{kN} / \mathrm{m} 2$ and $181 \mathrm{kN} / \mathrm{m} 2$, and the CBR value between $26.8 \%$ and $59.6 \%$. The result, therefore, shows that most of the failures are caused by the following: design inadequacies, inadequate drainage facilities, infiltration of surface runoff into the underlying course, growth of shrubs, and base failure.
\end{abstract}

(C) 2016 The Author(s). Published by TAF Publishing.

\section{INTRODUCTION}

In ancient times there was nothing more than a sparse network of tracks for humans to use in order to reach the feeding and drinking places. These tracks differed only slightly from the tracks made by any other mammal for the same purpose, except that obstacles e.g. boulders, were removed from the more important routes and thorn

\footnotetext{
*Corresponding author: Bello, A. A.

E-mail: adefemisola@yahoo.com
}

bushes trimmed back by humans. More elaborate lines of communication than these simple tracks did not appear until the increasing number of people in certain areas and the social structure and organization of communities demanded more permanent contact between communities [1] and [2].

In the pre-colonial days, the dominant mode of overland transportation was porters and draught animals over bush paths and tracks. But, in 1904 a cart road for mules and oxcarts were built to reduce the strain of securing porters for 
the British officials. The first road for motorized vehicles in Nigeria was, however, built in 1906 from Ibadan to Oyo. By 1914 there were 3,200 kilometres of roads in Nigeria. In 1926, the kilometres rose to 41,780 kilometres. By 1992, the total kilometres of Federal and State roads for motorized vehicles in Nigeria amounted to 51,428.98 kilometres. In terms of road length, the Federal government is responsible for $22 \%$ of roads in Nigeria, while state and local authorities are equally responsible for $27 \%$ and $51 \%$ of road network across Nigeria respectively [3]. Right from the colonial days to the present, there are three major classes of roads in Nigeria:

(i) Trunk Road "A"

(ii) Trunk Road "B"

(iii) Trunk Road " $\mathrm{C}$ "

Trunk Road "A" forms the skeleton of the national road grid. It cuts across regional boundaries in the country. It even extends to the international borders of neighbouring West African countries. Notable examples are Ijebu odeBenin Expressway, Abuja-Kaduna Expressway, LagosIbadan Expressway, Akure-Ilesa road, etc. In addition the Badagry-Republic of Benin road is a prominent international highway that links Nigeria with the neighbouring Republic of Benin. This class of road is constructed, maintained and financed by the Federal government through the Federal Ministry of Works and Housing.

Trunk Road "B" is the second category of main roads in Nigeria. It links the major cities within States with the State headquarters. These roads are financed by the State governments. They are tarred roads. The primary objective is to enhance the socio-economic development of the States.

Trunk Road "C" is local feeder roads constructed and maintained by the Works Department of local government authorities in Nigeria. This class of roads is usually untarred and seasonal in nature. For instance, it links villages and communities in the remote parts of each local government region.

The issue of highway maintenance and management is a complex issue in Nigeria, the reason being that the supply of road facilities in Nigeria cuts across various categories of public agencies. For example, the Federal Ministry of Works and Housing constructs and maintains the Trunk Road "A". Likewise the State Ministry of Works and Works Department of local government authorities construct and maintain Trunk road $B$ and $C$ respectively.

Flexible pavements are constructed of several layers of natural granular material covered with one or more waterproof bituminous surface layers, and as the name implies, is considered to be flexible. A flexible pavement will flex (bend) under the load of a tyre. The objective with the design of a flexible pavement is to avoid the excessive flexing of any layer, failure to achieve this will result in the overstressing of a layer, which ultimately will cause the pavement to fail. In flexible pavements, the load distribution pattern changes from one layer to another, because the strength of each layer is different. The strongest material (least flexible) is in the top layer and the weakest material (most flexible) is in the lowest layer. The reason for this is that at the surface the wheel load is applied to a small area, the result is high stress levels, deeper down in the pavement, the wheel load is applied to larger area, and the result is lower stress levels thus enabling the use of weaker materials [4].

These are asphalt pavements (sometimes called bituminous pavements), which may or may not incorporate underlying layers of stabilized or unstabilized granular materials on a prepared subgrade. These types of pavements are called "flexible" since the total pavement structure bends (or flexes) to accommodate traffic loads [5].

Pavement distresses are visible imperfections on pavement surface. They are symptoms of the deterioration of pavement structures. Most, if not all, agencies that have implemented a Pavement Maintenance Management System (PMMS) collect periodic surface distress information on their pavements through distress surveys. Distress evaluation, or condition survey, includes detailed identification of pavement distress type, severity, extent, and location. To combine these details, an index is assigned to each pavement which is transferred to a general rating. Every highway agency either develops pavement distress evaluation procedure or selects a developed one for its pavement condition survey.

Regardless of the size of the highway network or the sophistication of the PMS procedure, most PMS strategies can offer assistance at two levels: the network level and the project level. Network level information provides management with broad-based data about the entire system. Information for planning purposes and fiscal analysis is often provided by the network data. On the other hand, project level information can include specific details about engineering design, construction and cost accounting. Obviously the data required for each level differ considerably. Network level required disaggregate data that reflect the general pavement condition. However, project level needs detailed and specific data on expected 


\section{distresses}

In general, distress density starts its propagation process very slowly, but it accelerates more at a later stage. There are factors that affect rate of propagation. These factors may include pavement condition, traffic levels and distress severity. The distress density propagation on a new or recently overlaid pavement sections having excellent condition is expected to be slower than on pavement sections with poor condition. A distress is expected to behave differently on pavement sections subjected to different traffic levels [6].

\section{A. Brief Description of Study Area}

Odo-otin local government with headquarters at Okuku was created in 1976 following the Local Government reforms introduced during the Murtala/Obasanjo regime. It is located at Latitude $801^{\prime} 0.01$ ' and Longitude of 40 42 ' 0 " with an area of $294 \mathrm{~km} 2$ and a population of 134,110 .

Odo-otin Local Government area is situated within the tropics, and it is characterized by two alternating seasons, namely, the wet and the dry. The wet season is associated with annual rainfall of about $1300 \mathrm{~mm}$, spread between the months of April and October, with a relative lull, often referred to as the "August break" about July to August. The dry season is from about November to March. Usually, the dust laden cool winds, commonly referred to as harmattan, blow across the area between November and February.
Relative humidity varies from about 30\% in JanuaryMarch to about $60 \%$ in April-December. Mean annual temperature ranges from 28 to 320C, with maximum values during the months of February to May.

Vegetation cover in the study area is the deciduous forest type, characterized by dense vegetation with tall trees, climbers and bushy undergrowths. However, human activities such as settlements, cultivation and bush burning have commonly transformed the vegetation into secondary forest. Its soils are easy to farm. Because of the high seasonal rainfall with the high temperature, there is tendency for lateritic soil to constitute the major soil types in Ibadan due to the leaching of the mineral nutrient of the soil.

A study of the soil and geological maps of Nigeria after [7] and [8], respectively, show that the study area lies within southwestern Nigeria basement complex which forms part of the African crystalline shield. The basement complex is composed predominantly of folded gneisses, migmatite, schist and quartzite of the Precambrian age. The rock is characterized by mafic and felsic bands. The mafic bans are composed essentially of amphiboles and biotite while the felsic components are quartz and feldspars. The surficial geology consists of alluvium, laterite soils and basement rocks outcrops; three varieties of laterite soils are found on the peneplain; namely Older Laterites, Younger Laterities and Autochthonous Laterites.

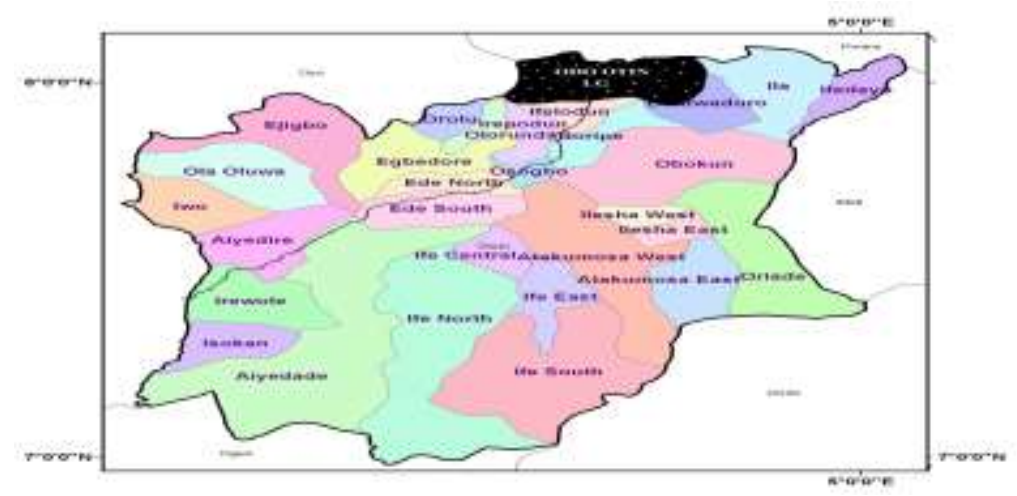

Fig. 1. Map of Osun showing Odo otin local government

\section{METHOD OF INVESTIGATION \\ B. Pavement Condition Survey and Visual Inspection}

Initial visit were made to the site to examine the pavement conditions of some selected pavements in Odo otin local government, which helps to visually identify the stage of the pavement and also the types of failures that had occured and some few causes that caused the failure. Some information collected during the initial site visits includes:

- Pavement condition survey of the road

- Photograph of existing pavement condition: this helps to show and keep record of the type of pavement failure or errors that occurred on the road

- Visual identification of pavement distress and causes: 
this helps to evaluate the stage and location of the pavement in Odo otin local government in order to help with the laboratory test

- Pavement drainage and other environment condition that can affect the pavements: availability of the drainage and present stage of the drainage helps to determine the causes of pavement failure in some areas

\section{Collection of Samples and Laboratory Testing}

Samples were collected from specific area which helps to determine which certain materials have been selected for the construction of the pavement in the area and the properties of the materials used. The following tests are to be carried out in the laboratory on the soil samples.

\section{Moisture Content Test}

This method is used to determine the percentage of water in a sample by drying the sample to a constant weight. The water content is expressed as the percentage, by weight, of the dry sample:

$$
\% W=\frac{A-B}{B} \times 100
$$

Where:

$\% \mathrm{~W}=$ Percentage of moisture in the sample,

A = Weight of wet sample (grams), and

$\mathrm{B}=$ Weight of dry sample (grams)

\section{E. Particle Size Analysis Test}

The importance of these tests is to identify and classify the soil. This helps to determine the type of soil used per layer

Analysis:

Percentage of mass retained $=\frac{\text { mass reatained }}{\text { total mass }} \times 100 \%$

\section{F. Atterberg-Limit Test}

This test is performed to determine the plastic and liquid limits of a fine grained soil. The Liquid Limit (LL) is arbitrarily defined as the water content, in percent, at which a part of soil in a standard cup and cut by a groove of standard dimensions will flow together at the base of the groove for a distance of $13 \mathrm{~mm}(1 / 2 \mathrm{in}$.) when subjected to 25 shocks from the cup being dropped $10 \mathrm{~mm}$ in a standard liquid limit apparatus operated at a rate of two shocks per second. The Plastic Limit (PL) is the water content, in percent, at which a soil can no longer be deformed by rolling into $3.2 \mathrm{~mm}(1 / 8 \mathrm{in}$.) diameter threads without crumbling.

\section{G. Compaction Test}

The sample specimens tested were prepared by mixing the relevant quantity of dry soil samples previously crushed to pass through BS No.4 sieve with $4.76 \mathrm{~mm}$ aperture as outlined by Head (1992) [9] as well as Albrecht and Benson (2001) [10]. The specimens were moulded at water content in the range $6.5-22.5 \%$ and four different compactive efforts similar to those that might be achieved in the field.

The compaction method used was the West African Standard (WAS) compaction as outlined in the Nigerian General Specification [11]. Five to seven batches of soil each weighing $2.5 \mathrm{~kg}$ were placed in a tray and mixed with tap water. The modified Proctor compactive effort involved the use of the same mould with a $4.5 \mathrm{~kg}$ rammer falling from a height of $450 \mathrm{~mm}$ applying 10 blows each and compacting in 5 layers. The West African Standard compactive effort is the conventional energy level commonly used in the region [12].

\section{H. Specific Gravity}

It is important to determine the specific gravity of fine grained soil, so as to determine the compactness of the soil and identify minerals present in the soil

Analysis:

Specific gravity $=\frac{\mathrm{M} 2-\mathrm{M} 1}{(\mathrm{M} 4-\mathrm{M} 1)-(\mathrm{M} 3-\mathrm{M} 2)}$

M1 = mass of pycnometer , M2 = mass of pycnometer + dry soil

M3 = mass of pycnometer + water + soil

M4 = mass of pycnometer + water

\section{Unconfined Compressive Strength Test}

Unconfined compression test was carried out on soil specimens previously mixed with tap water and compacted at moulding water contents in the range of 6.5 22.5\% using British Standard Light energy. Compacted specimens were sealed in plastic bags and allowed to stand for at least 24 hours before trimming and testing

\section{J. California Bearing Ratio (CBR) Test}

The California Bearing Ratio (CBR) is a penetration test for evaluation of the mechanical strength of road sub grades and base courses. It was developed by the 
California Department of Transportation in the 1930's. The CBR is used for measuring the load-bearing capacity for new pathways, road and airstrips or for soils already under paved areas. The harder the surface, the higher the rating [8]

Analysis:

1. CBR value is expressed as a percentage of the actual load causing the penetrations of $2.5 \mathrm{~mm}$ or $5.0 \mathrm{~mm}$ to the standard loads mentioned above. Therefore,

$C B R=\frac{\text { load carried by specimen }}{\text { load carried by standard specimen }} \times 100$

2. The greatest value calculated for penetrations at $2.5 \mathrm{~mm}$ and $5.0 \mathrm{~mm}$ will be recorded as the CBR value

\section{RESULTS AND DISCUSSIONS}

K. Site Visit and Data Collection

During the site visitation and sample collection stage, photographs of the roads were collected, in order to know and examine the current state of the road and drainage. See annex for details

\section{Pavement Condition Survey}

The results of the roads selected randomly within Odo Otin Local Government area were analyzed using the Pavement Condition Rating (PCR). Seven roads were surveyed with route numbers TP1 to TP7 indicated in the table below. From the analysis carried out, the PCR rating scale for TP4, TP6 and TP7 were in a good condition due to the fact that there was less distress on the road. TP3 and TP5 were in a satisfactory condition. TP1 and TP2 were observed to be in a poor condition. See annex for the rating form used in calculating the PCR. During this route survey, it was also observed that only T4 and T7 conform to the standard width of $7.30 \mathrm{~m} \mathrm{(3.65} \mathrm{m} \mathrm{x} \mathrm{2)}$ for two lane highway section roads as specified [9]. With the entire roads dimension listed in the table below, none of the road has road furniture expected such as walkway or median. This makes them unsafe for pedestrians walking along those roads.

Assessment on the drainage system was carried out to determine the efficiency of the drainage and relate it to the possible causes of the pavement distress. All the drainage system was made of block and concrete wall, with all of them not having a major discharge outlet which may connect to a water body for continuous flow.

Based on the outcome of this study, only road TP6 and TP7 have effective drainage, but can be predicted for them to have blockage or erode other roads in the nearest future due to no discharge outlet. For other roads, they have no drainage which leads to major causes of some distress all around those roads.

TABLE 1

SHOWING PCR VALUES OF ROADS ASSESSED

\begin{tabular}{lllllc}
\hline \hline Route no & \multicolumn{1}{c}{ Description } & \multicolumn{1}{c}{$\begin{array}{c}\text { Road distance } \\
(\mathrm{km})\end{array}$} & $\begin{array}{c}\text { Road width } \\
(\mathrm{m})\end{array}$ & Functional classification & PCR value \\
\hline TP1 & Iyalaje Road & 0.425 & 6.3 & Residential collector & 46.32 \\
TP2 & Okesina Road & 0.875 & 6.6 & Residential collector & 44.36 \\
TP3 & Cedars Road & 0.550 & 6.3 & Residential collector & 66.33 \\
TP4 & Igbaye Road & 2.200 & 7.2 & Community collector & 88.04 \\
TP5 & Olopade Oyinlola Road & 1.350 & 6.8 & Residential collector & 56.66 \\
TP6 & Makanjuola Road & 1.200 & 6.8 & Residential collector & 93.44 \\
TP7 & School Road & 0.400 & 16.5 & Residential collector & 96.28 \\
\hline \hline
\end{tabular}


TABLE 2

SHOWING SAMPLING POINT ACROSS ROAD SECTIONS

\begin{tabular}{clcc}
\hline Sample Number & \multicolumn{1}{c}{ Location } & Depth $(\mathrm{m})$ & Constituent materials \\
\hline T1 & Iyalaje Road CH0+005 & 0.7 & Silty clay \\
T2 & Iyalaje Road CH0+105 & 0.7 & Silty clay \\
T3 & Okesina Road CH0+005 & 0.7 & Silty clay \\
T4 & Okesina Road CH0+200 & 0.7 & Silty \\
T5 & Cedars Road CH0+050 & 0.7 & Clayey \\
T6 & Cedars Road CH0+250 & 0.7 & Silty \\
T7 & Igbaye Road CH0+035 & 0.7 & Clayey \\
T8 & Igbaye road CH0+750 & 0.7 & Silty gravel \\
T9 & Olopade O Road CH0+032 & 0.7 & Silty \\
T10 & Olopade O Road CH0+800 & 0.7 & Clayey gravel \\
T11 & Makanjuola Road CH0+020 & 0.7 & Silty clay \\
T12 & Makanjuola Road CH1+050 & 0.7 & Silty clay \\
T13 & School road CH0+050 & 0.7 & Silty clay \\
\hline
\end{tabular}

\section{Sample Collection and Laboratory Testing}

Thirteen trial pits were dug from seven selected roads with each road having two pits at considerable intervals except road $\mathrm{T} 7$ which has no subsequent failed section on the pavement. The depth of the trial pit was $0.7 \mathrm{~m}$ on both failed and unfailed sections of the selected road pavements. The geotechnical properties of the analyzed soil samples are discussed and presented in the Table 2 below.

\section{N. Moisture Content}

The natural moisture content of samples T1 to T13 are $9.1 \%, 8 \%, 9.8 \%, 10.0 \%, 13.8 \%, 10.2 \%, 8.1 \%, 10.1 \%$, $10.2 \%, 9.8 \%, 8.2 \%, 10.2 \%$ and $9.9 \%$.

\section{o. Specific Gravity}

The specific gravity of the tested soil samples lies between 2.54 and 2.65. The standard range of values for specific gravity of lateritic soil in Nigeria lies between 2.60 and 2.80, most of the samples lie between the range except for samples T1, T2, T6, T7 and T9 which are not in the range specified.

\section{P. Atterberg-Limit}

The liquid limits value of the samples $\mathrm{T} 1$ to $\mathrm{T} 13$ are
$19 \%, 27.1 \%, 22.7 \%, 19.5 \%, 47.6 \%, 24.6 \%, 35.6 \%, 17.3 \%$, $21.1 \%, 30.5 \%, 18.2 \% 20.4 \%$ and $24.5 \%$ while the plastic limit values of the samples are $14.1 \%, 22.5 \%, 17.7 \%$, $17.6 \%, 30.4 \%, 20.8 \%, 22.5 \%, 15.4 \%, 17,7 \%, 22.5 \%$, $13.2 \%, 15.4 \%$ and $20.1 \%$ and also the plasticity index values are $4.9 \%, 4.6 \%, 5 \%, 1.9 \%, 17.2 \%, 3.8 \%, 13.1 \%$, $1.9 \%, 3.4 \%, 8 \%, 5 \%, 5 \%$ and $4.4 \%$. The maximum limits for liquid limit and plastic limits for subgrade materials are $40 \%$ and $14 \%$ respectively. Hence, all the samples can be used except for $\mathrm{T} 5$ whose plasticity index is $17 \%$.

\section{Q. Particle Size Distribution}

The percentages of samples passing through No. 200 BS sieves for samples $\mathrm{T} 1$ to $\mathrm{T} 13$ are $38.8 \%, 24.6 \%, 34.2 \%$, $20.6 \%, 31.2 \%, 29.8 \%, 27.6 \%, 31.6 \%, 33 \%, 19 \%, 36 \% 33 \%$ and $8.8 \%$ with their graphs below. According to AASHTO classification, samples T2, T4 and T13 are A-1-b subgroup, samples $\mathrm{T} 3, \mathrm{~T} 6, \mathrm{~T} 8, \mathrm{~T} 9, \mathrm{~T} 10$ and $\mathrm{T} 12$ are $\mathrm{A}-2-4$ subgroup, while samples T1, T11, T5 and T7 are A-4, A-4, A-2-7 and A-2-6 respectively while under USCS classification, samples T1, T2, T3, T11, T12 and T13 have a group symbol of SC-SM and group name silty clayey sand, samples T4, T6, T8 and T9 have group symbol of SM and group name silty sand, while samples T5,T7 and T10 have group symbol SC and group name clayey sand. Base on the AASHTO classification chart, it is noted all the samples except for samples T1 and T11 are excellent to good soils while samples $\mathrm{T} 1$ and $\mathrm{T} 11$ are fair to bad soils. 


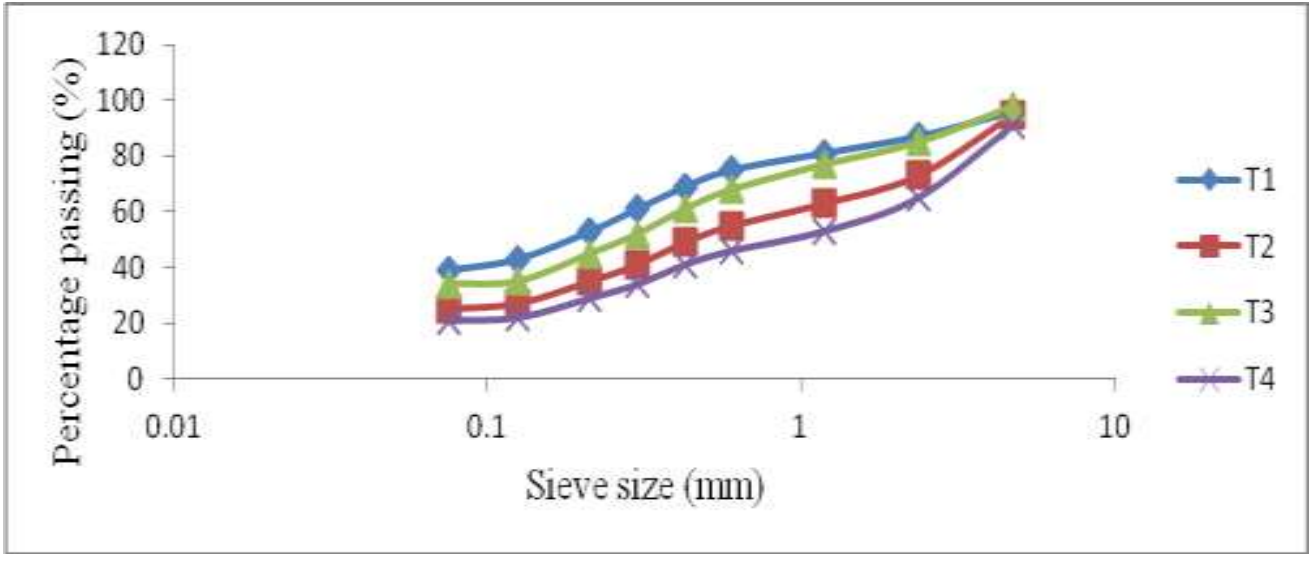

Fig. 2. Particle size distribution of the samples T1 to T4

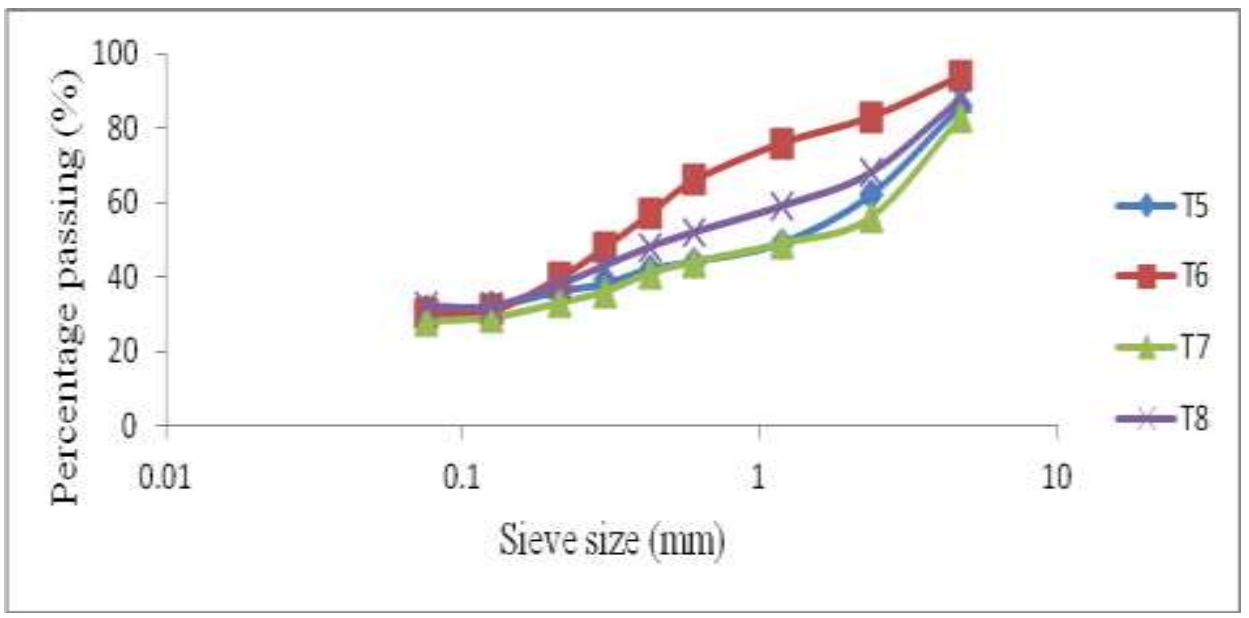

Fig. 3. Particle size distribution of the samples T5 to T8

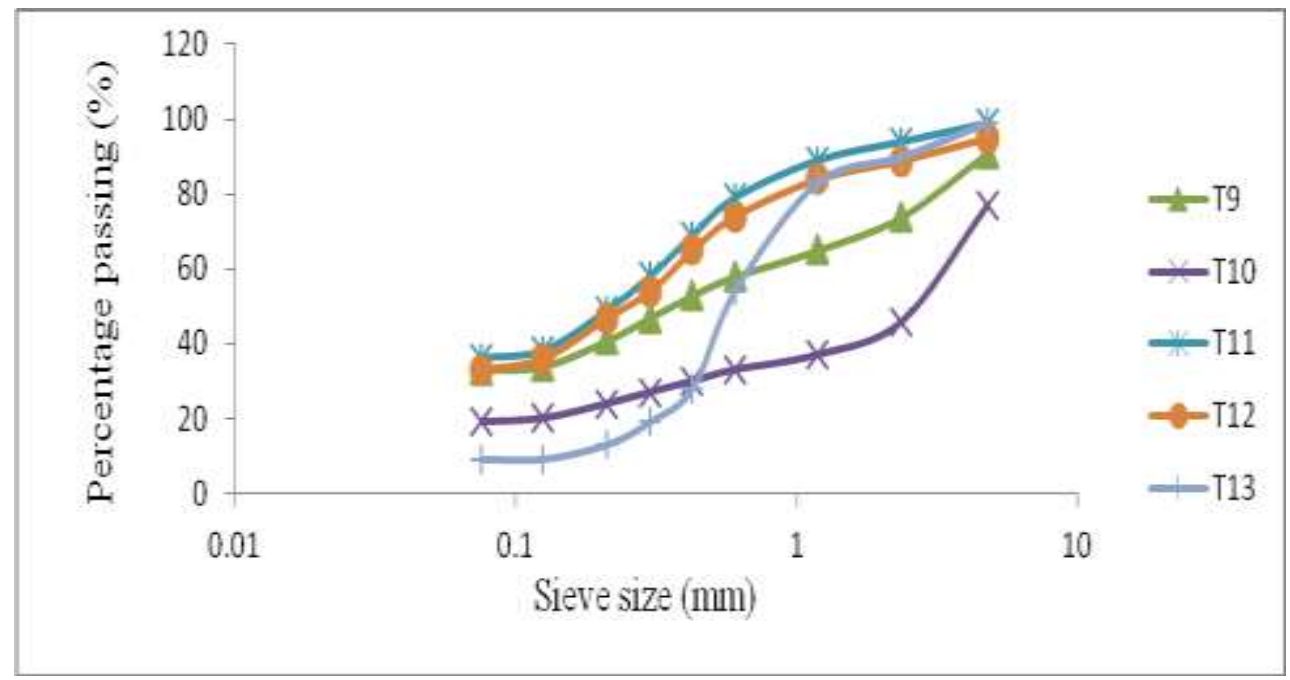

Fig. 4. Particle size distribution of the samples T9 to T13

\section{R. Compaction Test}

The West African standard of compacting soils was used on the soil samples collected. The Maximum Dry
Density (MDD) and the Optimum Moisture Content (OMC) of the various samples are listed below. The compaction curves for the analyzed soil samples show that sample T5 has the highest optimum moisture content 
of $16.7 \%$ while $\mathrm{T} 12$ has the lowest optimum moisture content of $8 \%$, sample $\mathrm{T} 4$ has the highest maximum dry density of $1.85 \mathrm{Mg} / \mathrm{cm}^{3}$ while sample $\mathrm{T} 5$ has the lowest maximum dry density of $1.53 \mathrm{Mg} / \mathrm{cm}^{3}$.

TABLE 3

SHOWING THE RESULTS OF THE COMPACTION

\begin{tabular}{ccc}
\hline \hline Samples & Maximum dry density $\left(\mathrm{Mg} / \mathrm{m}^{3}\right)$ & Optimum moisture content (\%) \\
\hline T1 & 1.66 & 11 \\
T2 & 1.77 & 8.5 \\
T3 & 1.71 & 11 \\
T4 & 1.85 & 9.8 \\
T5 & 1.53 & 16.7 \\
T6 & 1.71 & 11.2 \\
T7 & 1.60 & 15.2 \\
T8 & 1.71 & 10.5 \\
T9 & 1.76 & 10.5 \\
T10 & 1.76 & 10.3 \\
T11 & 1.68 & 8.9 \\
T12 & 1.74 & 8 \\
T13 & 1.77 & 12.2 \\
\hline \hline
\end{tabular}

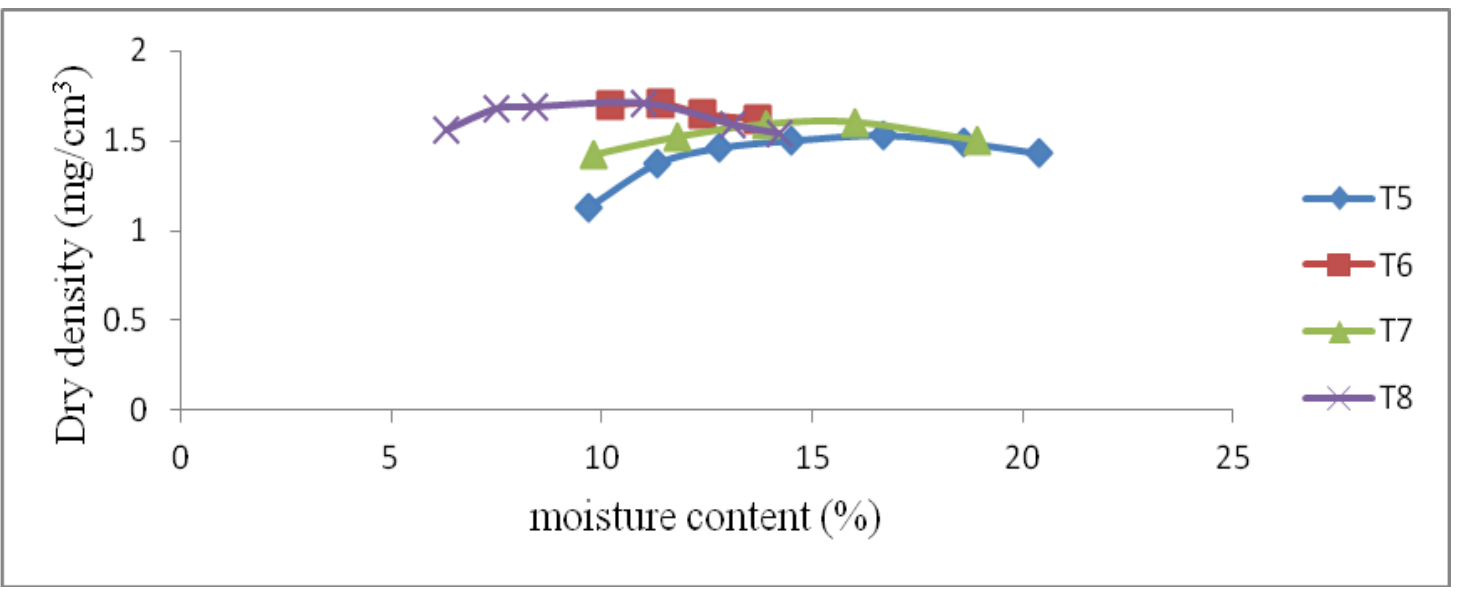

Fig. 6. Compaction curve of samples T5 and T8

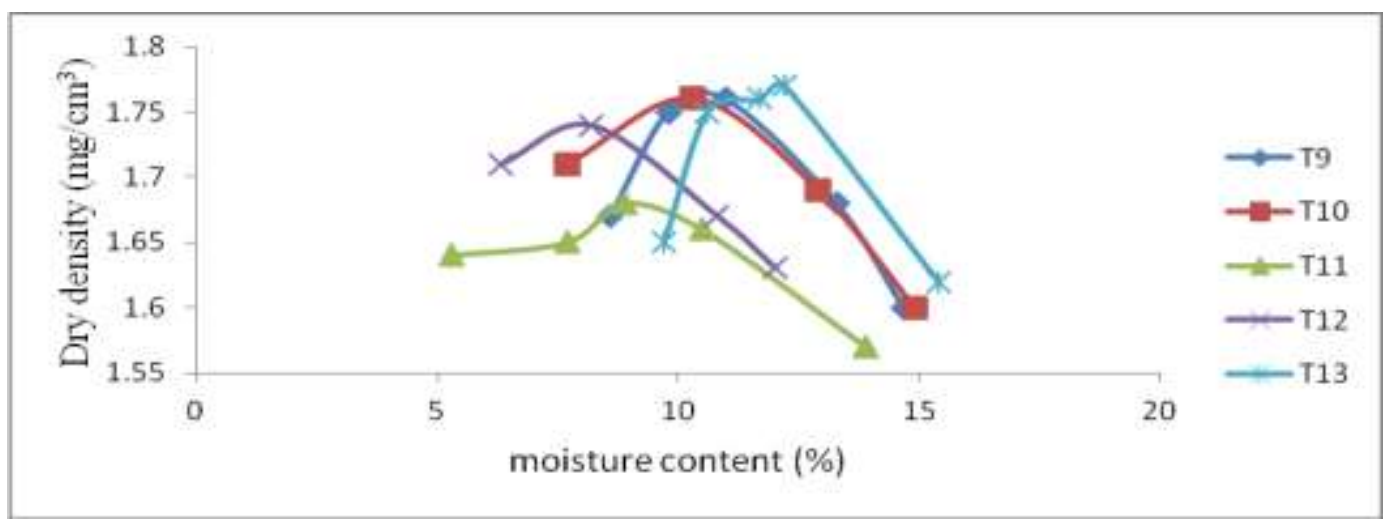

Fig. 7. Compaction curve of Samples T9 and T13 


\section{S. Unconfined Compressive Strength Test}

The unconfined compressive strengths (qu) of samples T1 to T13 are $181 \mathrm{kN} / \mathrm{m}^{2}, 41 \mathrm{kN} / \mathrm{m}^{2}, 79 \mathrm{kN} / \mathrm{m}^{2} 42 \mathrm{kN} / \mathrm{m}^{2}$, $101 \mathrm{kN} / \mathrm{m}^{2}, \quad 45 \mathrm{kN} / \mathrm{m}^{2}, \quad 89 \mathrm{kN} / \mathrm{m}^{2}, \quad 53 \mathrm{kN} / \mathrm{m}^{2}, \quad 53 \mathrm{kN} / \mathrm{m}^{2}$,
$53 \mathrm{kN} / \mathrm{m}^{2}, 137 \mathrm{kN} / \mathrm{m}^{2}, 61 \mathrm{kN} / \mathrm{m}^{2}$ and $42 \mathrm{kN} / \mathrm{m}^{2}$ with the graph of the samples as shown below. From the result above it was observed that soil with more cohesive properties tends to have more unconfined compressive strength.

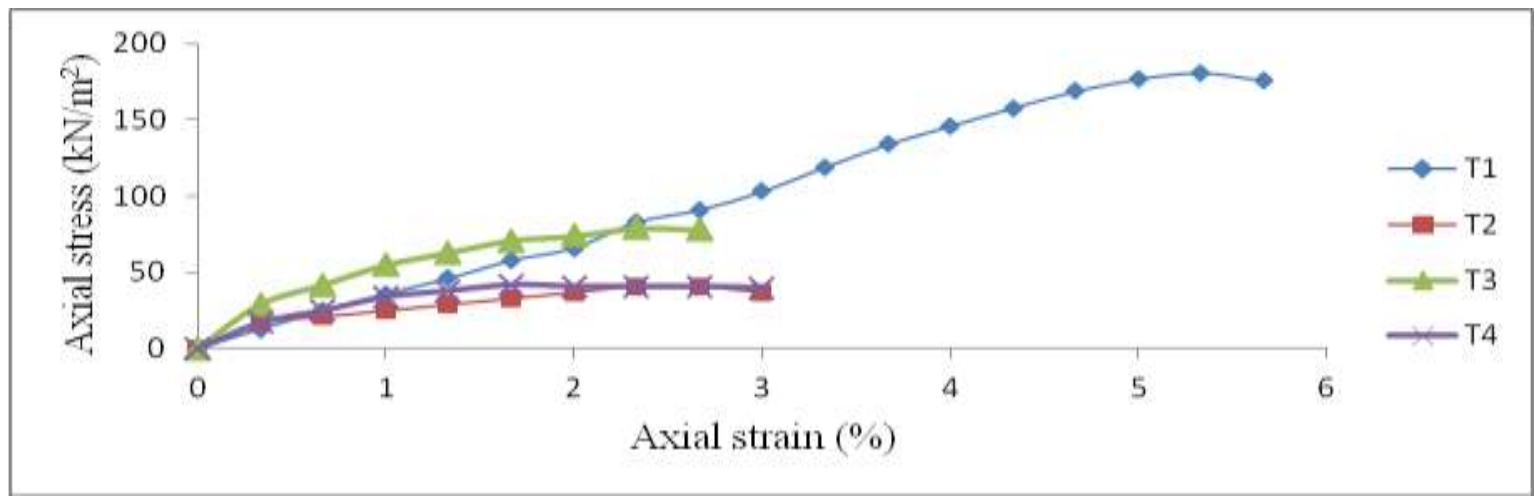

Fig. 8. Unconfined compressive strength graph of samples T1 and T4

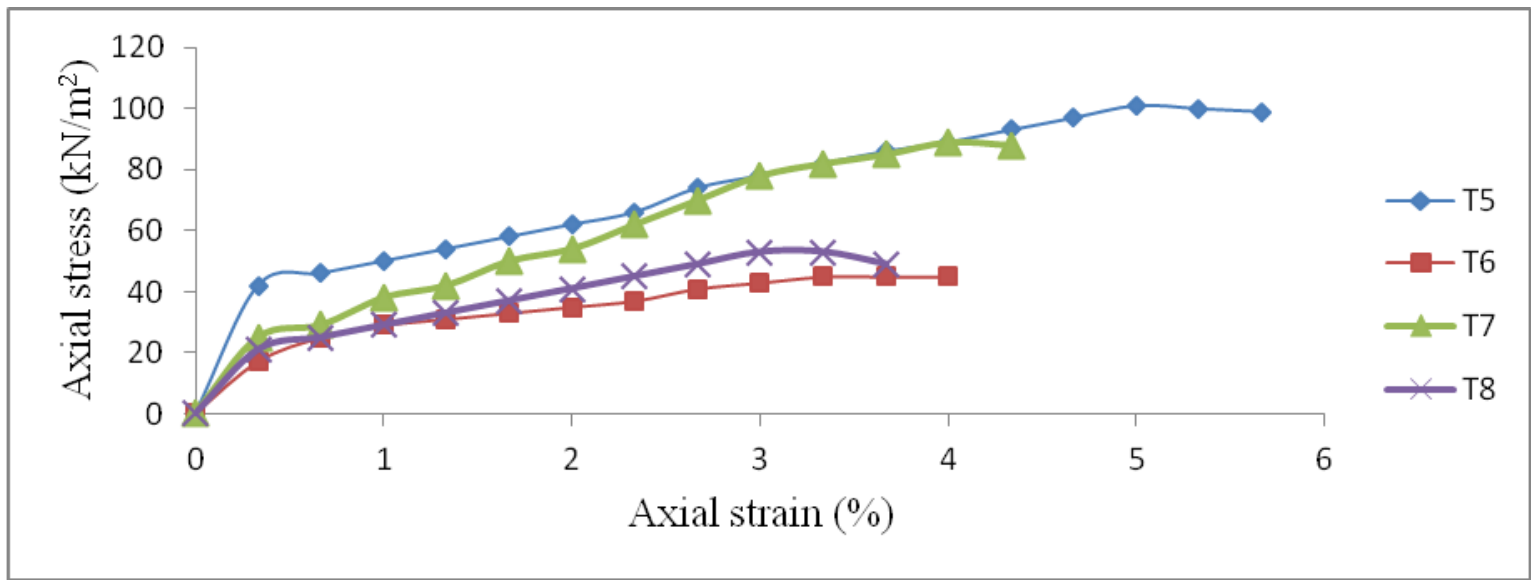

Fig. 9. Unconfined compressive strength graph of samples T5 and T8

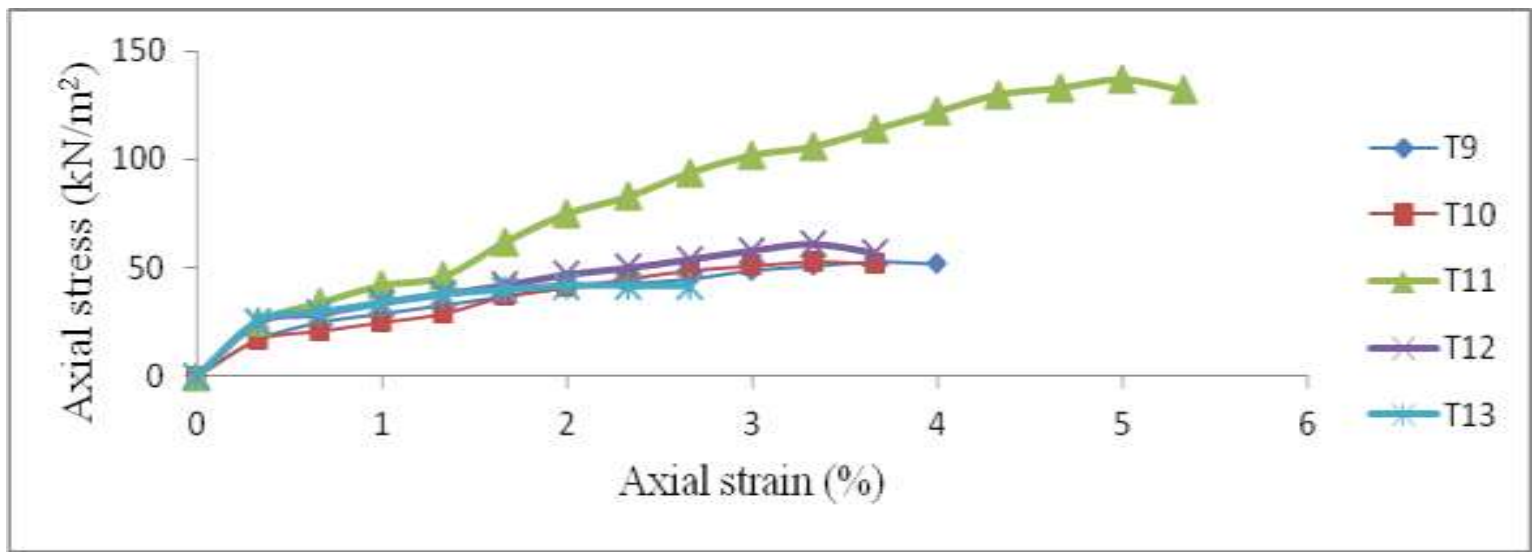

Fig. 10. Unconfined compressive strength graph of samples T9 and T13 


\section{T. California Bearing Ratio (CBR)}

The California bearing ratio result of samples T1 to T13 are 28.2\%, 53\%, 49.4\%, 59.6\%, 33.2\%, 53.3\%, $47.2 \%, 55.3 \%, 53.6 \%, 46.3 \%, 26.8 \%, 47.8 \%$ and $55.9 \%$ with the graph shown below. It was recommended that for soaked samples the values of CBR for subgrade, sub base and road base should not be less than $10 \%, 30 \%$ and $80 \%$ respectively, which implies that the entire sample can either be used for subgrade or sub base or both.

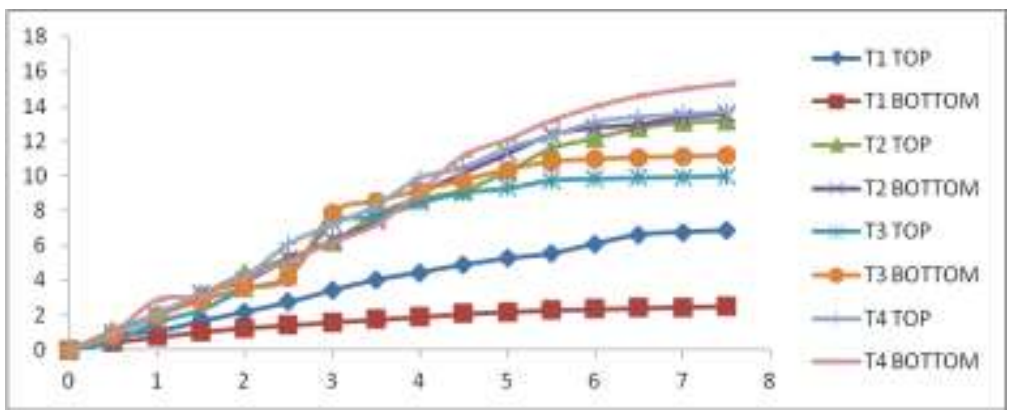

Fig. 11. California Bearing Ratio of T1 to T4

TABLE 4

SHOWING PHYSICAL PROPERTIES OF SOIL SAMPLES

\begin{tabular}{|c|c|c|c|c|c|c|c|c|c|c|c|c|c|}
\hline Samples & $\mathrm{T} 1$ & $\mathrm{~T} 2$ & $\mathrm{~T} 3$ & $\mathrm{~T} 4$ & $\mathrm{~T} 5$ & T6 & $\mathrm{T} 7$ & $\mathrm{~T} 8$ & T9 & $\mathrm{T} 10$ & T11 & $\mathrm{T} 12$ & $\mathrm{~T} 13$ \\
\hline$\%$ Passing $0.075 \mu \mathrm{m}$ & 39 & 25 & 34 & 21 & 31 & 30 & 28 & 32 & 33 & 19 & 36 & 33 & 9 \\
\hline Liquid limit (\%) & 19 & 27.1 & 22.7 & 19.5 & 47.6 & 24.6 & 35.6 & 17.3 & 21.1 & 30.5 & 18.2 & 20.4 & 24.5 \\
\hline Plastic limit (\%) & 14.1 & 22.5 & 17.7 & 17.6 & 30.4 & 20.8 & 22.5 & 15.4 & 17.7 & 22.5 & 13.2 & 15.4 & 20.1 \\
\hline Plastic index(\%) & 4.9 & 4.6 & 5 & 1.9 & 17.2 & 3.8 & 13.1 & 1.9 & 3.4 & 8 & 5 & 5 & 4.4 \\
\hline $\begin{array}{c}\text { Maximum dry } \\
\text { density }\left(\mathrm{Mg} / \mathrm{m}^{3}\right)\end{array}$ & 1.66 & 1.77 & 1.71 & 1.75 & 1.53 & 1.71 & 1.6 & 1.71 & 1.76 & 1.77 & 1.68 & 1.74 & 1.77 \\
\hline Optimum moisture (\%) & 11 & 8.5 & 11 & 9.8 & 16.7 & 11.2 & 15.2 & 10.5 & 10.5 & 10.3 & 8.9 & 8 & 12.2 \\
\hline CBR Un-soaked (\%) & 25.76 & 51.52 & 54.54 & 29.35 & 43.01 & 40.53 & 53.57 & 32.21 & 32.21 & 32.21 & 32.21 & 32.21 & 32.21 \\
\hline AASHTO & A-4 & $A-1-b$ & A-2-4 & $A-1-b$ & $A-2-7$ & $A-2-4$ & A-2-6 & A-2-4 & A-2-4 & $A-2-4$ & A-4 & A-2-4 & $A-1-b$ \\
\hline USCS & $\begin{array}{l}\text { SM- } \\
\text { SC }\end{array}$ & $\begin{array}{l}\text { SM- } \\
\text { SC }\end{array}$ & $\begin{array}{l}\text { SM- } \\
\text { SC }\end{array}$ & SM & SC & SM & SC & SM & SM & SC & $\begin{array}{l}\text { SM- } \\
\text { SC }\end{array}$ & $\begin{array}{l}\text { SM- } \\
\text { SC }\end{array}$ & $\begin{array}{l}\text { SM- } \\
\text { SC }\end{array}$ \\
\hline Specific gravity & 2.57 & 2.54 & 2.6 & 2.67 & 2.61 & 2.54 & 2.57 & 2.62 & 2.57 & 2.65 & 2.6 & 2.61 & 2.6 \\
\hline
\end{tabular}




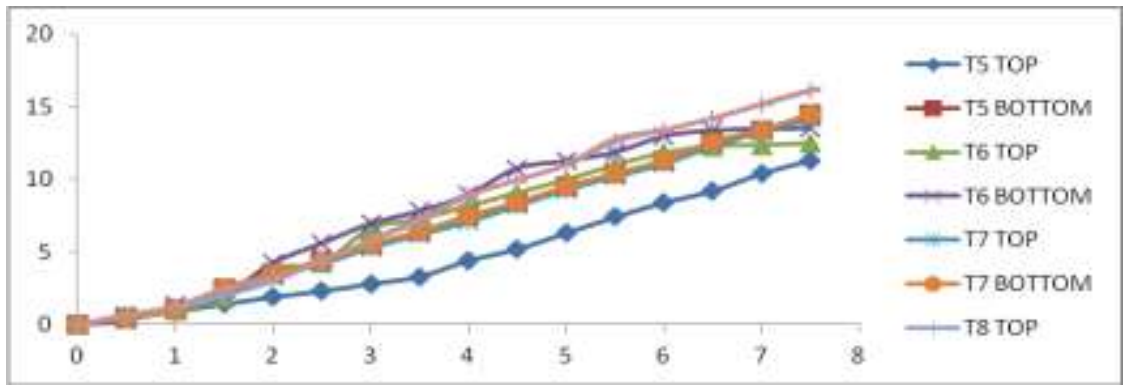

Fig .12. California bearing ratio of T5 to T18

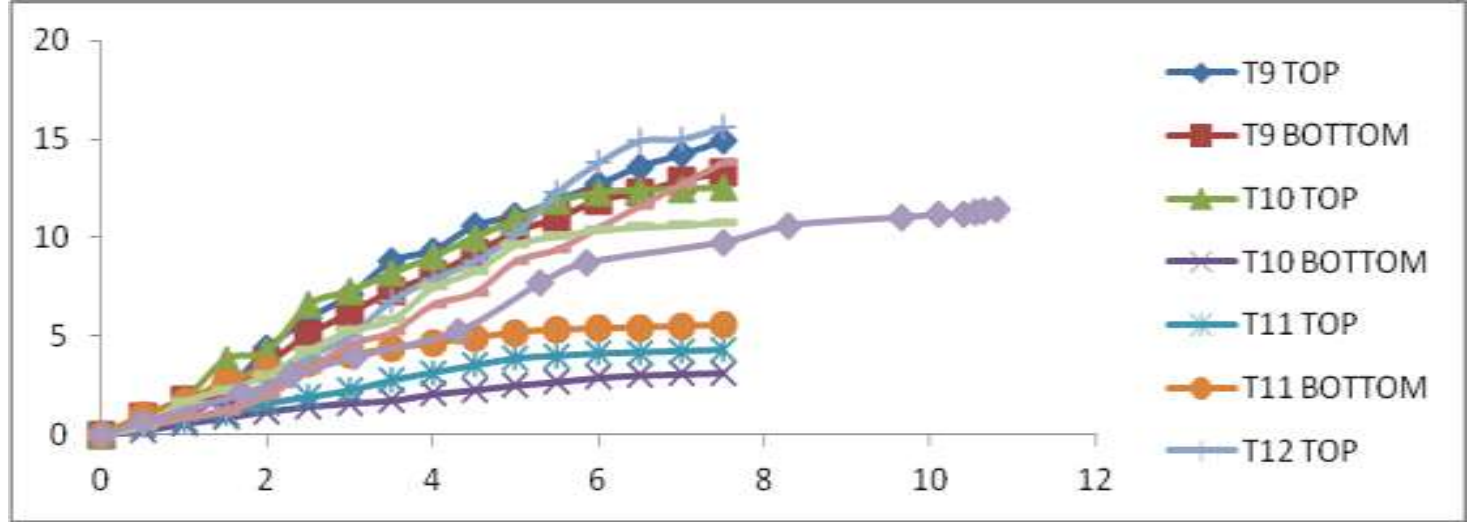

Fig. 13. California bearing ratio of $\mathrm{T} 9$ to $\mathrm{T} 13$

\section{CONCLUSION AND RECOMMENDATION}

\section{Conclusion}

Flexible pavements of some selected highways in Odootin Local Government have been assessed. Results obtained from the field survey show that some of the road needs proper maintenance, while some needs to be redesigned, this is due to the results obtained from the PCR for samples TP1 to TP7 which are 46.32, 44.36, 56.66, 88.04, 66.33, 93.44 and 96.28. Road having PCR less than 50 should be redesigned and reconstructed while other greater than 50 can be properly maintained. Also from the field survey only TP7 and TP3 are suitable for adequate movement of vehicles due to the limit of the pavement width whereby other roads have width less than $7.2 \mathrm{~m}$ for two lane road. There is adequate need for drainage construction for this is the major cause of failures in the area such as alligator cracks, potholes raveling e.t.c.; only two roads namely TP6 and TP7 have drainage which can also predict to have blockage and causes erosion for the road and other adjacent road.

Geotechnical analysis of soil samples from selected roads has liquid limit ranging between $17.3 \%$ and $47.6 \%$, the plastic limit ranging between $13.2 \%$ and $30.4 \%$ and the plastic limit also between $1.9 \&$ and
$17.2 \%$, most samples were classified as A-1-a and A-2-7 under AASHTO classification except T1 and T11 which are A-4 with the USCS also SC-SM, SC or SM. Therefore soils that range between $A-1-a$ and $A-2-7$ are excellent to good soils while A-4 soils are fair soil. The specific gravity ranges between $2.54-2.67$, the maximum dry density of the soil is $1.85 \mathrm{Mg} / \mathrm{cm}^{3}$ and minimum dry density of the soil is $1.53 \mathrm{Mg} / \mathrm{cm}^{3}$ for sample $\mathrm{T} 4$ and $\mathrm{T} 5$ respectively. The maximum optimum moisture content is $16.7 \%$ for sample $\mathrm{T} 5$ and lowest optimum moisture content is $8 \%$ for sample $\mathrm{T} 12$. The highest and lowest unconfined compressed strengths are $181 \mathrm{kN} / \mathrm{m}^{2}$ and $41 \mathrm{kN} / \mathrm{m}^{2}$ and the CBR value is between $59.6 \%$ and $26.8 \%$.

Finally, after evaluation of the pavements in Odo Otin Local Government Area, Okuku, Osun State, SouthWestern Nigeria, it will be appropriate to conclude that the failure of pavement in Odo Otin Local Government could be attributed to the following: design inadequacies, inadequate drainage facilities, infiltration of surface runoff into underlying course, growth of shrubs, base failure, lack of good quality control by supervisory staffs during construction phase and lack of effective routine maintenance by the concerned agencies. 


\section{Recommendations}

Roads transportation is very essential in every aspect of daily activities and this depends on the effectiveness of the road pavement. To achieve this, adequate attention should be given to the following recommendations:

i. Road pavement having little distress should be quickly treated and those beyond treatment should be properly rehabilitated or redesigned.

ii. Proper and adequate construction of drainage and linking the drainage to a good flow water body

iii. More soil samples should be collected within the case study area for detailed work on their engineering properties.

iv. The ministry of works (Highway Department) should enforce strict compliance to construction specification and appropriate construction practice and use of adequate materials

v. All newly constructed roads should be thoroughly supervised by qualified engineers for safe and efficient road construction.

vi. Osun Road Maintenance Agency (ORMA) should develop a progam for maintaining and evaluating the condition of existing and newly constructed flexible pavements within the Local Government Area.

\section{REFERENCES}

[1] K. Jenkins, "Introduction to road pavements," in Hitchhiker's Guide to Pavement Engineering, 2006, pp. 1-11.
[2] A. A. Bello, J. A. Ige and U. A. Adebanjo, "Flexible pavement assessment of selected highways in Orolu local government South Western Nigeria," British Journal of Applied Science and Technology, vol. 7, no. 1, pp. 46-61, 2015. DOI: 10.9734/BJAST/2015/15172

[3] J. A. Odeleye, "Towards financing and planning road safety audit operations in Nigeria," IATSS Research, vol. 24, no. 2, pp. 85-96, 2000. DOI: 10.1016/S03861112(14)60032-7

[4] A. Sharad and A. Gupta, "Pavement deterioration and its causes," International Journal of Innovative Research and Development, vol. 2, no. 4, 437-450, 2013.

[5] O. Popoola and 0. Apampa, Introduction to Highway Construction. Jeddiah Publisher, Abeokuta: Nigeria, 2011, pp 46-68.

[6] G. Laura. (2010). SOILS proficiency testing California bearing ratio (CBR). Proficiency Australia, 2010, pp 17.

[7] F. A. Akintola, "Geology and geomorphology," in Nigeria in Maps, R. M. Barbour, Ed. Hodder and Stoughton, London, UK, 1982.

[8] O. Areola, "Soils," in Nigeria in Maps, R. M, Barbour, Ed. Hodder and Stoughton, London: UK, 1982.

[11] Federal Ministry of Work and Housing, General Specifications for Roads and Bridges, vol. 2, Federal Highway Department, Lagos: Nigeria, 1997.

[12] S. A. Ola, "Geotechnical properties and behaviour of some stabilized Nigerian lateritic soils," Quarterly Journal of Engineering Geology and Hydrogeology, pp. 11, no. 2, pp. 145-160, 1978. 


\section{APPENDIX}

Section

KEY

Date:

Log Mile to

FLEXIBLE PAVEMENT CONDITION

Rated by:

Sta:

to

RATING FORM

\begin{tabular}{|c|c|c|c|c|c|c|c|c|}
\hline \multirow{2}{*}{ DISTRESS } & \multirow{2}{*}{$\begin{array}{l}\text { Distress } \\
\text { Weight }\end{array}$} & \multicolumn{3}{|c|}{ SEVERITY* } & \multicolumn{3}{|c|}{ EXTENT $* *$} & \multirow{2}{*}{$\underset{\ldots T R}{\text { STR }}$} \\
\hline & & L & M & $\mathrm{H}$ & 0 & $\mathrm{~F}$ & $\mathrm{E}$ & \\
\hline RAVELING & 10 & $\begin{array}{c}\text { Slight Loss of } \\
\text { 3and }\end{array}$ & Open Texture & $\begin{array}{l}\text { Rough of } \\
\text { pilited }\end{array}$ & $<20 \%$ & $20.50 \%$ & $>50 \%$ & \\
\hline BLEEDING & 5 & not rated & $\begin{array}{c}\text { Bot and } A g 9 \\
\text { valible }\end{array}$ & Biack Surloce & $40 \%$ & $10-30 \%$ & $230 \%$ & \\
\hline PATCHING & 5 & $=1 e^{2}$ & et $y d^{2}$ & $31 \mathrm{yd}^{2}$ & sto/mile & $10-20 \mathrm{mile}$ & $320 / \mathrm{mila}$ & \\
\hline POTHOLESIDEBONDING & 10 & $\begin{array}{l}\text { depth \&1" } \\
\text { area \&1 y } \mathrm{g}^{2}\end{array}$ & $\begin{array}{l}<1,>1 \mathrm{yd}^{2} \\
>1,-1 \mathrm{yd}^{2}\end{array}$ & $\begin{array}{l}>1 \text { and } \\
>1 \mathrm{yd}^{2}\end{array}$ & $\cos 10$ & 5.t0imilo & $>10 \mathrm{mv}$ & $\checkmark$ \\
\hline CRACK SEALING DEFIC. & 5 & \multicolumn{3}{|c|}{ Not comsidered } & $<20 \%$ & $20.50 \%$ & $250 \%$ & \\
\hline RUTTING & 10 & $<1 / 4^{*}$ & $1 / 4-1^{*}$ & $31^{\circ}$ & $<20 \%$ & $20-50 \%$ & $>50 \%$ & $\checkmark$ \\
\hline SETTLEMENTS & 10 & $\begin{array}{c}\text { Nictic osble } \\
\text { eflect an rite }\end{array}$ & $\begin{array}{c}\text { Same } \\
\text { Discondort }\end{array}$ & Poor Rido & $2 \mathrm{mi}$ & $24 i m i$ & $\times 4: \mathrm{mi}$ & \\
\hline CORRUGATIONS & 5 & $\begin{array}{l}\text { Natic eabie } \\
\text { eflect on rise }\end{array}$ & $\begin{array}{c}\text { Some } \\
\text { Discandon }\end{array}$ & Paoc Fide & sto\% & $10-30 \%$ & $>90 \%$ & \\
\hline $\begin{array}{l}\text { WHEEL TRACK } \\
\text { CRACKING }\end{array}$ & 15 & $\begin{array}{l}\text { Single/muntipie } \\
\text { cracks <1/4" }\end{array}$ & $\begin{array}{l}\text { Multible ceechs } \\
\qquad 1 / 4^{*}\end{array}$ & $\begin{array}{l}\text { Aligator }>1 / 4^{*} \\
\text { Spelling }\end{array}$ & $20 \%$ & $20-50 \%$ & $250 \%$ & $\checkmark$ \\
\hline $\begin{array}{l}\text { BLOCK \& TRANSVERSE } \\
\text { CRACKING }\end{array}$ & 10 & $\begin{array}{l}\text { e1/4*" wide, no } \\
\text { Spaling }\end{array}$ & $\begin{array}{l}1 / 4-1 \text { " abng } \\
\text { min Slangth }\end{array}$ & $\begin{array}{l}21 \% \text { a bng m in } \\
\text { Slength }\end{array}$ & $20 \%$ & $20.50 \%$ & $250 \%$ & $\checkmark$ \\
\hline $\begin{array}{l}\text { LONGITUDINAL JOINT } \\
\text { CRACKING }\end{array}$ & 5 & $\begin{array}{l}\text { Singlo. e1/4: } \\
\text { no Spating }\end{array}$ & $\begin{array}{c}\text { singie/muisple } \\
1 / 4-1^{*} \text {, somo } \\
\text { Spaling }\end{array}$ & $\begin{array}{c}\text { Multipie, }>11^{*} \\
\text { Spaling }\end{array}$ & $<20 \%$ & $20-50 \mathrm{~s}$ & $>50 \$$ & \\
\hline EDGE CRACKING & 5 & Night, $<1 A^{*}$ & $\begin{array}{l}\text { >1:4", sorse } \\
\text { Spaling }\end{array}$ & $\begin{array}{l}\text { Pi/s", } \\
\text { moderate } \\
\text { Spalng }\end{array}$ & $<20 \%$ & $20-50 \%$ & $>50 \%$ & \\
\hline RANDOM CRACKING & 5 & $81 / 4^{2}$ & $1 / 4-1^{2}$ & $>15$ & $<20 \%$ & $20.50 \%$ & 2504 & $\sqrt{v}$ \\
\hline
\end{tabular}

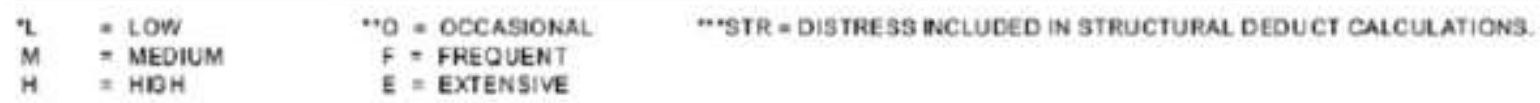

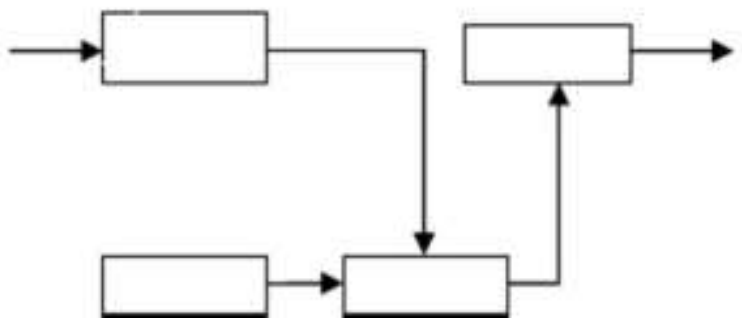

SUMMARY OF PCR DEDUCT VALUES

\begin{tabular}{|c|c|c|c|c|c|c|c|c|}
\hline \multirow[t]{2}{*}{ Distress Type } & \multirow{2}{*}{$\begin{array}{l}\text { Distress } \\
\text { Weight }\end{array}$} & \multicolumn{3}{|c|}{ Severity } & \multicolumn{3}{|c|}{ Extent } & \multirow[t]{2}{*}{ Tota } \\
\hline & & $\mathrm{L}$ & M & $\ldots \mathrm{H}$ & 0 & $\mathrm{~F}$ & $\mathrm{E}$ & \\
\hline Raveling & 10 & 0.3 & 0.6 & 1 & 0.5 & 0.8 & 1 & \\
\hline Bleeding & 5 & 0.8 & 0.8 & 1 & 0.6 & 0.9 & 1 & \\
\hline Corrugation & 5 & 0.4 & 0.8 & 1 & 0.5 & 0.8 & 1 & \\
\hline
\end{tabular}




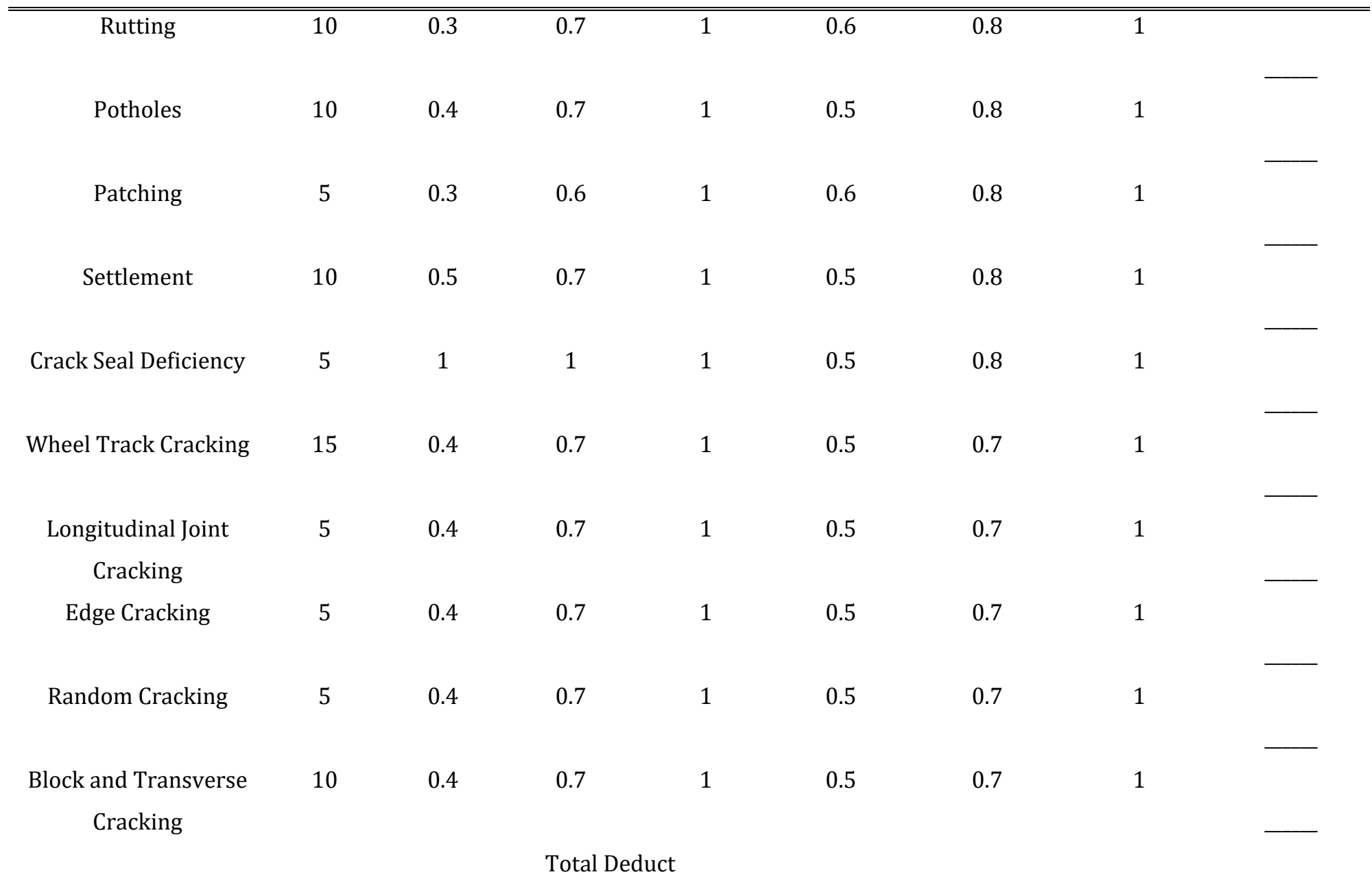

$100-$ Total Deduct $=$ PCR

$\mathrm{L}=$ Low $\quad 0=$ Occasionally

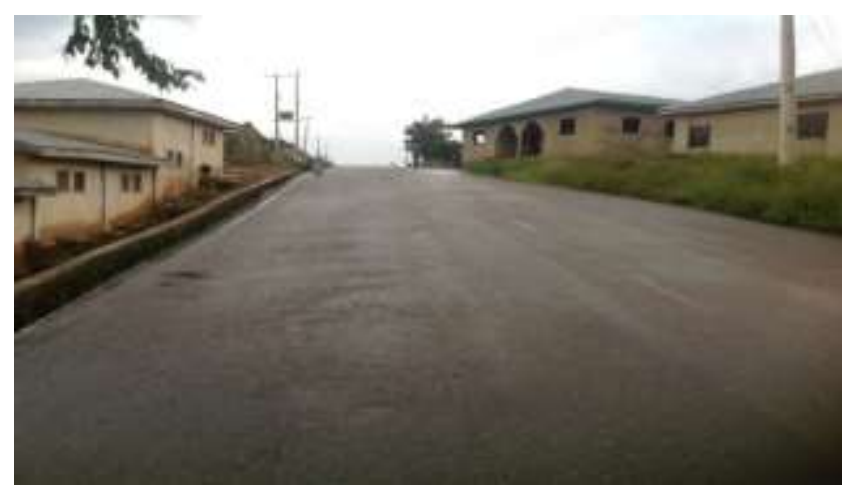

Plate 1: Showing a pavement in good working condition with adequate drainage facility in place (School road).

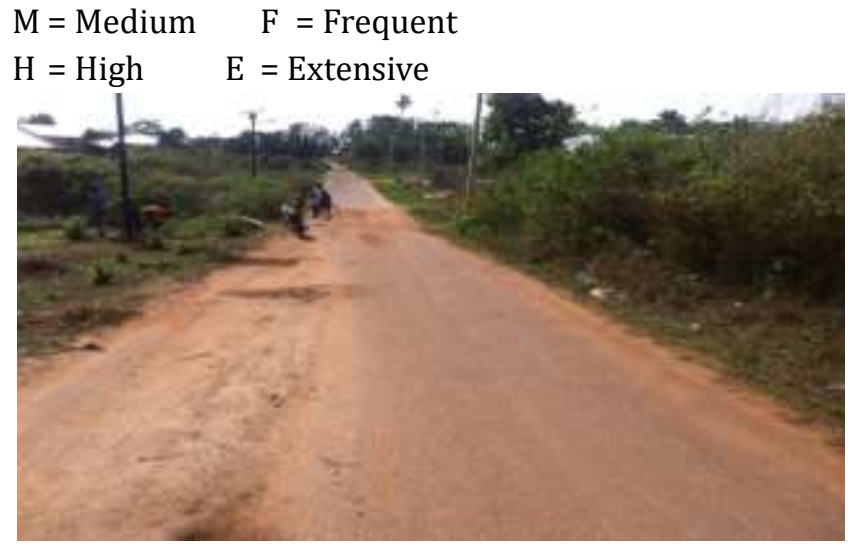

Plate 2: Showing the view of Olopade Oyinlola road with potholes 


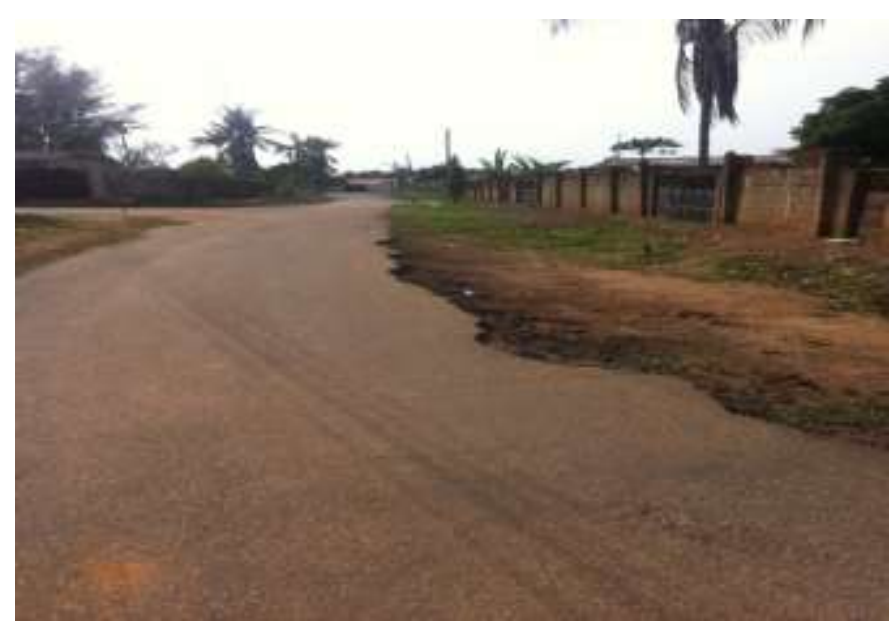

Plate 3: Showing the view of Cedars Road with edge cracks along the road

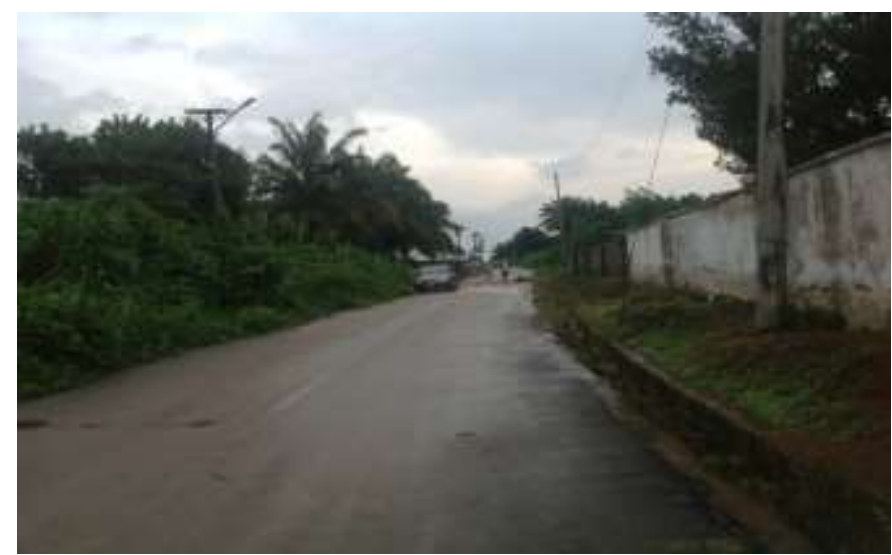

Plate. 5. Showing the view of Makanjuola Road with drainage

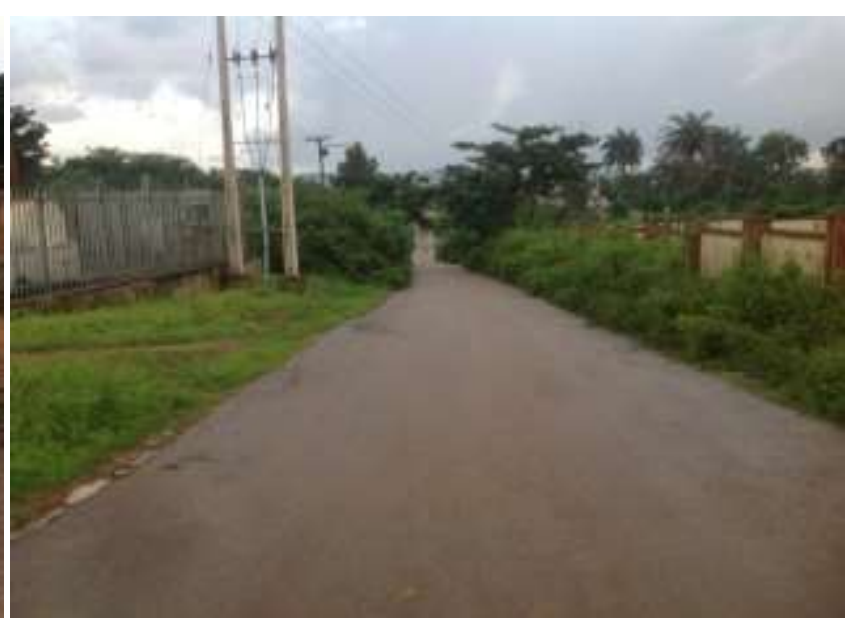

Plate. 4. Showing the view of Okesina Road surface with little defects along road

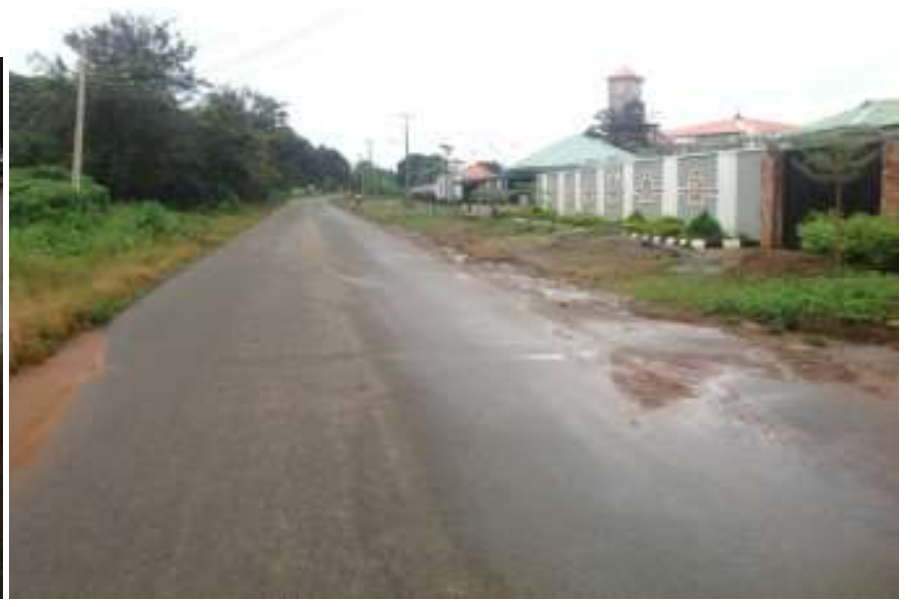

Plate 6: Showing the view of Igbaye Road with no drainage

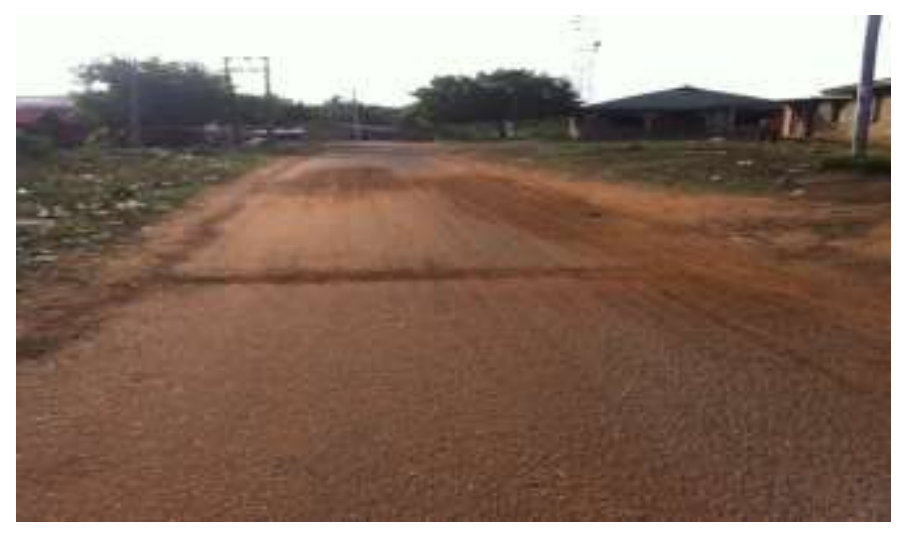

Plate. 6. Showing the view of Iyalaje Road with surface defect 